\title{
EPA re-evaluates StarLink license
}

US regulatory officials continued to wrestle in December with a request from Aventis CropScience (Research Triangle Park, NC) to permit limited human consumption of its StarLink corn. Although the company has been removing products that contain StarLink from the food supply, Aventis representatives are requesting that, with so little of it now remaining in the pipeline, it be approved for consumption because public health is not in jeopardy. Scientists on a panel advising the US Environmental Protection Agency (EPA; Washington, DC) on the company's request came close to agreeing with those arguments, concluding that despite a "medium likelihood" that StarLink-containing foods include an allergen, there is a "low probability" of it affecting consumers.

The StarLink episode began last October when activist coalition Genetic Engineering Food Alert (GEFA; Washington, DC) reported finding traces of this GM corn in food products (Nat. Biotechnol. 18, 1136, 2000). The difficulty for Aventis is that StarLink contains a Cry 9 C gene, encoding a variant of the insecticidal protein derived from the soil bacterium Bacillus thuringiensis that EPA did not approve for human food use. Indeed, when StarLink was registered, agency officials specified that it and other types of corn grown within 660 feet be used "only in animal feed, industrial non-food uses such as ethanol production, and [for] seed increase." Further, agency officials said that "Aventis CropScience.... is liable for the actions of its customers in regard to meeting the terms and limitations of this registration."

During much of October and November, Aventis, EPA and other federal officials, farmers, food manufacturers, grocers, and others became embroiled in a massive product recall throughout the US, as well as additional efforts to cull StarLink from exports to countries such as Japan that rejected the GM corn even for animal feed uses. However, even as Aventis cooperated in these recall efforts, farmers, grain handlers, and others were sharply criticizing the company for disrupting operations and jeopardizing their livelihoods.

For example, early in November the National Grain and Feed Association (Washington, DC) called on the US Department of Agriculture (USDA; Washington, DC) to compensate this industry for losses resulting from commingling StarLink with other corn. In another development, a group of Midwestern farmers whose corn harvest was threatened because of its inadvertent contamination with
StarLink filed a class action lawsuit in December against Aventis, seeking compensatory and punitive damages.

In the face of this burgeoning outcry, Aventis petitioned EPA to grant a "time-limited exemption" to allow StarLink in food products for the next four years - a change in status that would relieve some of the economic and legal pressures facing the company. In response, EPA officials quickly assembled a scientific advisory panel (SAP), asking its members to assess the public health risks if StarLink were consumed.

During a 12-hour public meeting late in November, the panel members listened to EPA officials and other federal scientists who have been analyzing reports claiming StarLinkassociated allergies. They also received a scattergun of public comments. Much of the scientific focus was on whether Cry9C protein can be detected in StarLink and food products derived from it, whether it can induce allergic responses, and whether enough is present to pose a risk to those who consume such foods.

For example, Karl Klontz of the US Food and Drug Administration (FDA; Rockville, $\mathrm{MD})$ and Carol Rubin of the federal Centers for Disease Control and Prevention (Atlanta, GA) described their efforts to analyze a series of 35 reports involving 44 individuals who claimed to have experienced allergic reactions following consumption of corn-containing foods. The SAP concluded that at least seven of those cases might represent genuine allergic food reactions. To test whether those responses might be due to StarLink exposure, the panel urged that blood samples from those individuals be tested for specific antibodies to Cry9C, noting that these testing efforts warranted the "highest priority."

Meanwhile, public comments tended to focus on what EPA should do regarding the Aventis petition. For example, Margaret Wittenberg, representing the Whole Foods Market (Austin, TX) chain, says that, "because the biotechnology industry has waved the banner of 'sound science," granting an exemption to Aventis "would erode public trust." Moreover, she adds, "To allow animal feed into the food supply sends the wrong message to consumers." Another critic, Joseph Mendelson of the Center for Food Safety (Washington, DC), agrees, urging EPA officials not to "award Aventis for illegal behavior."

But biotechnology industry representatives disagree with those assertions on several grounds. For instance, Michael Phillips of the Biotechnology Industry Organization (BIO; Washington, DC) calls the current situation facing Aventis "intolerable" because it effectively imposes a "zero tolerance" on the amount of StarLink that may enter the food supply, essentially disregarding how low the public's exposure to this material actually might be. He also points out that new results from tests commissioned by $\mathrm{BIO}$ indicate that Cry9C is substantially degraded during food processing, further reducing any likelihood that it could trigger food allergies. Susan Harlander of Biorational Consultants (St. Paul, $\mathrm{MN}$ ) also urges EPA to support the Aventis request, saying that not doing so risks "losing consumer confidence" because of the confusing message from federal officials indicating that StarLink poses no public health risk but nonetheless is not fit for human consumption.

"Both the panel's recommendations and the public comments. . .will be used to guide the EPA," says Stephen Johnson, deputy assistant administrator of the agency, which still had not decided what to do by mid December. Meanwhile, FDA officials attended the EPA SAP meeting, but restricted their participation to providing scientific analysis, pointing out that the principal regulatory responsibilities for the Aventis StarLink decision rest with EPA.

USDA Secretary Dan Glickman is taking a bolder stance. "Across the federal government we are diligently and expeditiously working to address all of the issues and concerns that have arisen with respect to StarLink corn," he says. "USDA is working with industry and our trading partners to protect the integrity of our markets, both domestic and international. We are also working with our sister agencies to ensure that foods containing StarLink corn are not distributed." Glickman also points to another issue complicating the StarLink story, namely the movement of genes into the environment and the rest of the agricultural food chain, noting that it is important to "determine what the public policy implications are" from such gene movement. Indeed, Adventis' Larry Somerville says that at least several carloads of corn have tested positive for Cry9C looking like that in StarLink but derive from another unlicensed source.

In more general terms, Glickman says, "As we move through and beyond StarLink, we should not refrain from asking the hard questions and searching for better answers to the challenges raised by biotechnology. Some might argue that the StarLink episode will lead to greater government involvement. . .but it's important to remember that this problem may not have occurred had industry complied with the terms of its license."

Jeffrey L. Fox 